\title{
Estimation of apparent digestibility coefficient of plant feed ingredients (soybean and sunflower meal) for Labeo Rohita
}

\author{
Farkhanda Asad", Tooba Rehman, Noureen Aziz Qureshi, Nimra Tahir \\ Department of Wildlife \& Fisheries, Government College University, Faisalabad, Pakistan
}

Email address:

far_khane@yahoo.com(F. Asad),naina.tabi89@gmail.com(T. Rehman)

\section{To cite this article:}

Farkhanda Asad, Tooba Rehman, Noureen Aziz Qureshi, Nimra Tahir. Estimation of Apparent Digestibility Coefficient of Plant Feed Ingredients (Soybean and Sunflower Meal) for Labeo Rohita. American Journal of Biomedical and Life Sciences. Vol. 1, No. 1, 2013, pp. 8-11. doi: 10.11648/j.ajbls.20130101.12

\begin{abstract}
The present study was carried out to estimate the apparent nutrient digestibility of soybean meal and sunflower meal for Labeo rohita. Prior to being fed with test diets, the fish were acclimatized on reference diet for about one week. Test diet-1 (soybean meal) and test diet-2 (sunflower meal) was prepared by mixing reference diet and test feed ingredients (soybean meal and sunflower meal) in a 70:30 ratio. Representative samples of feed and feces of fish were analyzed for the dry matter, crude protein, crude fat, crude fiber, ash and gross energy following AOAC (1990) to determine the apparent digestibility of soybean and sunflower meal for Labeo rohita. The outcomes showed that the apparent digestibility coefficient (ADC) of dry matter was highest $(64.50 \% \pm 3.5)$ for reference diet followed by soybean meal $(34.5 \% \pm 2.50)$ and sunflower meal $(23.5 \% \pm 1.50)$. In case of crude protein, ADC was highest for sunflower meal $(77 \% \pm 3.0)$ followed by soybean meal $(63.5 \% \pm 2.50)$ and reference diet $(37.5 \% \pm 0.50)$ while the apparent crude fat digestibility coefficient was highest for soybean meal $(71.50 \% \pm 3.50)$ followed by sunflower meal $(70.50 \% \pm 0.50)$ and reference diet $(61.00 \% \pm 3.0)$. Percentage value of apparent digestibility for crude fiber was maximum for test diet $2(31.50 \% \pm 3.50)$ followed by test diet $1(11.50 \% \pm 0.50)$ and reference diet $(9.50 \% \pm 0.50)$. In case of ash, ADC was highest for reference diet $(46.50 \% \pm 2.5)$ followed by test diet $2(27.50 \% \pm 2.5)$ and test diet $1(15.50 \% \pm 1.5)$. Values for gross energy were $(43 \% \pm 2.0),(42.5 \% \pm 0.5)$ and $(26.5 \% \pm 7.5)$ for test diet 2 , test diet 1 and reference diet, respectively. These findings can be sum up as soybean meal and sunflower meal proved as a promising fish feed ingredient being more efficiently utilized and digested in Labeo rohita, thus fish meal can be efficiently replaced with plant ingredients in rohu diets.
\end{abstract}

Keywords: Labeo Rohita, Soybean Meal, Sunflower Meal, ADC (Apparent Digestibility Coefficient)

\section{Introduction}

As fish culture operations are being intensified and expensive conventional foodstuffs, there is a need to develop nutritionally balanced and economical diet that is well digested and provide the essential nutrients for optimal growth[1]. To date, nutritionists and feed manufacturers have focused their trials on determining which of the wide variety of foodstuffs available to the feed industry may be used to produce a lower cost fish diet. Fish production sector provides not only animal protein food security but also improve service and profits for poverty elimination in many developing countries[2]. The achievement of intensive and semi-intensive fish culture depends to a large degree on the application of appropriate feeds (nutritionally balanced and economical) although other physicalchemical parameters are also significant[3]. Extensive use of fish meal in fish feed industry and its limited supply, increased human consumption made it necessary to replace it by alternative and cheaper protein sources[4]. Plant byproducts are a promising source of protein and energy for the formulation of economical and nutritionally balanced fish feeds $[5,6]$.

Therefore the present study was designed to determine the apparent nutrient digestibility of plant feed ingredients (sunflower meal and soybean meal) for Labeo rohita.

\section{Material and Methods}

The experiment was conducted in Research Laboratory, Department of Wildlife and Fisheries, GC University, 
Faisalabad, Punjab.

\subsection{Experimental Fish}

Labeo rohita fingerlings collected from government fish seed hatchery, Satiana road, Faisalabad were allowed to acclimitize ambient conditions for one week in glass aquarium before initiating the trial. During acclimatization, fingerlings were fed on the reference diet at the rate of $4 \%$ live wet body weight.

\subsection{Feed Ingredients and Diet Preparation}

Reference diet contained fish meal as a sole source of protein whereas test diet 1 and 2 contained soybean meal and sunflower meal, respectively. Each test diet was prepared by mixing $70 \%$ reference diet and $30 \%$ of each of the test ingredients (soybean meal and sunflower meal). Reference diet and two test diets were prepared by linear formulation method through Winfeed 2.6 (WinFeed (UK) Ltd., Cambridge, UK). Feed ingredients viz, fish meal, rice polish, wheat bran, rice broken, sunflower meal and soybean meal were ground, sieved for adding into diets and mixed in a mixer for 30 minutes, where after fish oil will be gradually added, while mixing constantly. Eighty five $(85 \mathrm{ml})$ of water per $100 \mathrm{~g}$ of feed was slowly added into the mixed resulting in an appropriate texture dough, as for fish food[7]. Drying of feed was carried out in a convection oven at $350^{\circ} \mathrm{C}$ for $48 \mathrm{hrs}$. The percentage composition of reference and test diets is shown in table I.

Table 1. The percentage composition of reference and test diets.

\begin{tabular}{lccc}
\hline Iingredients & $\begin{array}{c}\text { Reference } \\
\text { Diet }\end{array}$ & $\begin{array}{c}\text { Test diet 1 } \\
\text { (Soybean meal) }\end{array}$ & $\begin{array}{c}\text { Test diet 2 } \\
\text { (Sunflower meal) }\end{array}$ \\
\hline Fish meal & 38 & 19.87 & 22.93 \\
Rice polish & 19.34 & 16.14 & 15.13 \\
Wheat bran & 20.78 & 17.59 & 16.34 \\
Rice broken & 15.05 & 9.57 & 8.77 \\
Fish oil & 4.83 & 4.83 & 4.83 \\
Vitamin premix & 1.00 & 1.00 & 1.00 \\
Chromic oxide & 1.00 & 1.00 & 1.00 \\
Test ingredient-1 & - & 30 & - \\
Test ingredient-2 & - & - & 30 \\
Total & 100 & 100 & 100 \\
\hline
\end{tabular}

Test ingredient (1): Soybean meal

Test ingredient (2): Sunflower meal

\subsection{Feeding Protocol and Fecal Collection}

After acclimatization, fingerlings were transferred randomly into glass aquaria[90L $\times 30 \mathrm{~W} \times 45 \mathrm{H}(\mathrm{cm})$ with 29 $\mathrm{L}$ water capacities each]. Two replicates of each diet were followed and in each replica forty fingerlings were stocked. Fish were given reference and test diets at the rate of $4 \%$ live wet body weight twice a day (morning and afternoon) in the feeding aquarium[8]. After feeding session of 2-3 hours, fingerlings were shifted in adjacent aquaria for fecal collection daily. Fecal was collected by siphoning carefully to avoid breaking of the thin fecal strings in order to minimize the nutrient leaching. The collected fecal material from each replicate was dried at room temperature (Temp $30-32^{\circ} \mathrm{C}$ ) on daily basis.

\subsection{Analytical Methods}

Representative samples of three diets and oven dried feces of each replica were homogenized individually using a mortar pestle and analyzed chemically by AOAC (1990) procedures: dry matter (DM) by oven drying at $105^{\circ} \mathrm{C}$; crude protein $(\mathrm{CP})$ by microkjeldahl analysis, crude fat by chloroform methanol extraction method through 10454 soxtec system HTz, crude fiber by ash-free residue digested with alkali and acid, ash through electric furnace. Chromic oxide $\left(\underline{\mathrm{Cr}}_{2} \underline{\mathrm{O}}_{3}\right)$ in dried samples of feed and feces was determined according to the procedure described by[9] through UV/VIS2001 spectrophotometer. Apparent digestibility coefficient of nutrients for each experimental diet was calculated by using the standard method[10]. After finding the possible results, data of digestibility, growth and body composition was subjected to analysis of variance (ANOVA) and SPSS for statistical analysis and mean $\pm \mathrm{SE}$ values were calculated.

\section{Results}

Proximate nutrient analysis of feed, feces and estimation of chromic oxide $\left(\mathrm{Cr}_{2} \mathrm{O}_{3}\right)$ is shown in table 2 .

Table 2. Proximate nutrient analysis of feed, feces and estimation of chromic oxide $\left(\mathrm{Cr}_{2} \mathrm{O}_{3}\right)$.

\begin{tabular}{lccc}
\hline Component & $\begin{array}{c}\text { Reference } \\
\text { diet }\end{array}$ & $\begin{array}{c}\text { Test diet 1 } \\
\text { (Soybean } \\
\text { meal) }\end{array}$ & $\begin{array}{c}\text { Test diet 2 } \\
\text { (Sunflower } \\
\text { meal) }\end{array}$ \\
\hline \multicolumn{3}{c}{ Feed } & \\
Dry matter (\%) & $86.50 \pm 0.50$ & $96.05 \pm 0.82$ & $87.89 \pm 0.03$ \\
Crude protein (\%) & $25.46 \pm 0.31$ & $31.59 \pm 0.14$ & $25.53 \pm 0.37$ \\
Crude fat (\%) & $4.05 \pm 0.05$ & $10.64 \pm 0.14$ & $7.35 \pm 0.16$ \\
Crude fiber (\%) & $4.63 \pm 0.13$ & $8.57 \pm 0.00$ & $13.32 \pm 0.22$ \\
$\begin{array}{l}\text { Ash (\%) } \\
\text { Gross energy }\end{array}$ & $21.45 \pm 0.22$ & $23.5 \pm 0.50$ & $22.27 \pm 0.05$ \\
$\begin{array}{l}\text { Kcal/g) } \\
\text { Chromic oxide } \\
\text { (\%) }\end{array}$ & $400.1 \pm 0.09$ & $495.28 \pm 0.21$ & $436.25 \pm 0.14$ \\
& $0.78 \pm 0.00$ & $0.88 \pm 0.01$ & $0.97 \pm 0.00$ \\
Dry matter (\%) & $82.27 \pm 0.15$ & $92.50 \pm 0.50$ & $83.50 \pm 0.50$ \\
Crude protein $(\%)$ & $20.43 \pm 0.18$ & $16.23 \pm 0.13$ & $8.46 \pm 0.31$ \\
Crude fat (\%) & $2.37 \pm 0.12$ & $4.3 \pm 0.15$ & $0.06 \pm 0.01$ \\
Crude fiber (\%) & $3.29 \pm 0.16$ & $7.75 \pm 0.39$ & $12.08 \pm 0.03$ \\
$\begin{array}{l}\text { Ash (\%) } \\
\text { Gross energy }\end{array}$ & $10.1 \pm 0.1$ & $20.38 \pm 0.2$ & $21.50 \pm 0.5$ \\
$\begin{array}{l}\text { Kcal/g) } \\
\text { Chromic oxide }\end{array}$ & $379.55 \pm 0.19$ & $432.45 \pm 0.25$ & $396.03 \pm 0.01$ \\
\hline & $0.66 \% \pm 0.12$ & $0.51 \% \pm 0.12$ & $0.46 \% \pm 0.19$ \\
\hline
\end{tabular}

Apparent nutrient digestibility coefficients of dry matter, crude protein, crude fat, crude fiber, ash and gross energy 
of reference and test diets are shown in table 3 and Fig. 1.

Results obtained showed that the apparent digestibility coefficient (ADC) of dry matter was highest $(64.50 \% \pm 3.5)$ for reference diet followed by test diet $1(34.5 \% \pm 2.50)$ and test diet $2(23.5 \% \pm 1.50)$. In case of crude protein, ADC was highest for test diet $2(77 \% \pm 3.0)$ followed by test diet 1 $(63.5 \% \pm 2.50)$ and reference diet $(37.5 \% \pm 0.50)$. The apparent crude fat digestibility coefficient was highest for test diet $1(71.50 \% \pm 3.50)$ followed by test diet 2 $(70.50 \% \pm 0.50)$ and reference $\operatorname{diet}(61.00 \% \pm 3.0)$. In case of ash, ADC was highest for reference diet $(46.50 \% \pm 2.5)$ followed by test diet $2(27.50 \% \pm 2.5)$ and test diet 1 $(15.50 \% \pm 1.5)$. Values for gross energy were $(43 \% \pm 2.0)$, $(42.5 \% \pm 0.5)$ and $(26.5 \% \pm 7.5)$ for test diet 2 , test diet 1 and reference diet, respectively.

\section{Discussion}

Lower value of dry matter digestibility in rohu for test diet 2 (sunflower meal) may be due to the high carbohydrate content in it. Several other studies reported low dry matter digestibility in plant protein with high carbohydrate contents[11-13]. Low dry matter digestibility in sunflower meal may be due to comparatively high fiber content in it as fish cannot utilize non protein component effectively from plant material[14]. The apparent protein digestibility value of test diet 2 was comparable to the value observed by[8] higher than (68.1\%) reported by[15] and $69 \%$ reported by[16] by using hybrid striped bass (Morone chrysops $\times$ M.saxatilis) but lower than $(92 \%)$ reported by[17] using abalone (Haliotis midea). For test diet 1(soybean meal) crude fat digestibility value was comparable to the value $(69.75 \% \pm 0.95)$ observed by[18].

Percentage value of apparent digestibility for crude fiber was maximum for test diet $2(31.50 \% \pm 3.50)$ followed by test diet $1(11.50 \% \pm 0.50)$ and reference diet $(9.50 \% \pm 0.50)$. Again lower ash digestibility value of plant ingredients may be due to higher carbohydrate contents[19]. Reference[20] observed comparable value $(49.3 \%)$ of gross energy for sunflower meal using tilapia (Oreochromis niloticus). The apparent protein digestibility (APD) and energy retention increased with increase in the inclusion levels of plant proteins in the diets[17].

\section{Conclusion}

Hence results can be sum up as soybean meal and sunflower meal proved as a promising fish feed ingredient being more efficiently digested and utilized in Labeo rohita replacing fish meal. The palatability of soybean meal and its excellent nutritional value including high level of protein, corresponding amino acid profile and relatively high nutritional digestibility, proved to be a high-quality ingredient for this fish. Results obtained from present study could be useful as starting point for formulating cost effective nutritionally balanced fish diets by replacing fish meal with plant origin ingredients.

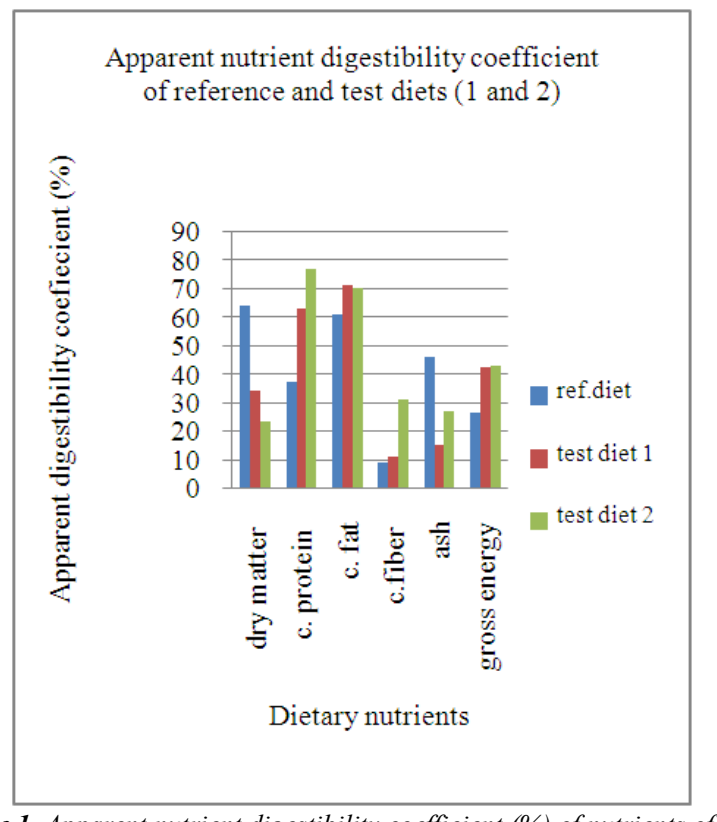

Figure 1. Apparent nutrient digestibility coefficient (\%) of nutrients of reference and test diets

\section{References}

[1] J. F. Mokolensang, S. Yamasaki, and Y. Onoue, "Utilization of shochu distillery by-products for culturing the common carp Cyprinus carpio". Int. J. Bio. Sci., vol, 3: 2003, pp. 502-507.

[2] B.A. Sheikh and S.A. Sheikh, "Aquaculture and integrated farming system". J. Agri., Agril. Engg. Vet. Sci, vol, 20: 2004, pp. 52-58.

[3] M. Abid, and M. Salim, "Efficacy of varying dietary protein levels on growth, feed conversion and body composition of Cirrhinus mrigala fingerlings" Pak. J. Lif. Soc. Sci., vol. 2: 2004, pp. 91-94.

[4] P. Siddhuraju, and K. Becker, "Preliminary nutritional evaluation of mucuna seed meal in common carp ;( Cyprinus carpio L.): An assessment by growth performance and feed utilization". Aquaculture, vol. 196: 2001, pp. 105-123.

[5] R.W. Hardy, "New developments in aquatic feed ingredients and potential of enzyme supplements". In: Advances en Nutricion Acuicola V. Memorias del V Simposium Internacional de Nutricion Acuicola, Merida, Yucatan, Mexico, 19-22 November (Ed. By L.E. Cruz-Suarez, D. Ricque-Marie, M. Tapia-Salazar, M.A. Olvera-Novoa and R. Civera-cerece-do). 2000, pp. 216-226

[6] D. M. Gatlin, F. T. Barrows, P. Brown, K. Dabrowski, T. G. Gaylord, R. W. Hardy, E. Herman, G. S. Hu, A. krogdahl, R. Nelson, K. Overturf, M. Rust, W. Sealey, D. Skonberg, E. J. Souza, D. Stone, R. Wilson, and E. Wurtele, "Expanding the utilization of sustainable plant products in aquafeeds": a review. Aquacult. Res., vol. 38: 2007, pp. 551-579.

[7] R.T. Lovell, "Nutrition and Feeding of Fish", 1989, p. 260. Van Nostrant- Reinhold, New York, USA

[8] U. Noreen, and M. Salim, "Determination of nutrient 
digestibility and amino acid availability of various feed ingredients for Labeo rohita". Int. J. Agri Bio., vol. 10: 2008, pp. 551-555.

[9] S. Divakaran, G.O. Leonard, and P.F. Ian, "Note on the methods for determination of chromic oxide in shrimp feeds". J. Agri. Food Chem., vol. 50: 2002, pp. 464-467

[10] L. A. Maynard, and J.K. Loosli, "Apparent digestibility measurement in feedstuffs for rainbow trout". In: Halver, J.E., K. Tiews (Eds.), Fish Nutr. Fish Feed Technology, vol. 2: 1969 , pp. 239-47.

[11] G.L. Allan, P. Scott, B.A. Mark, S.J.A. David, R.J. Stuart, F. Jane, and S.W. Rebecca, "Replacement of fish meal in diets for Australian silver perch Bidyanus bidyanus": In. Digestibility of alternative ingredients. Aquaculture., vol. 186: 2000, 293-310.

[12] W.E. Hajen, R.M.Beams, D.A.Higgs, and B.S. Dosanjh, "Digestibility of various feedstuffs by post-juvenile Chinook salmon (oncorhnchus ishawytscha) in sea water". Aquaculture, vol. 112: 1993, pp. 333-348.

[13] A. Laining, A.T. Rachmansyah, and W. Kevin, "Apparent digestibility of selected feed ingredients for humpback grouper, Cromileptes altivelis". Aquacult, vol. 218: 2003, pp. $529-538$

[14] S.D. Sugiura, F.M. Dong, C.K. Rathbone, and R.W., Hardy, "Apparent protein digestibility and mineral availabilities in various feed ingredients for salmonid feeds". Aquaculture, vol. 159: 1998, pp. 177-202

[15] T. Shipton, “The protein requirement for the south African abalone, Haliotis midae, Ph.D Dissertation, Rhodes University, Grahamstown, South Africa, 2000, p. 146

[16] T. G. Gaylord, S.D. Rawles, and D.M. GATLIN, "Amino acid availability from animal, blended, and plant feedstuffs for hybrid striped bass (Morone chrysops $\times$ M. saxatilis). Aquacult. Nutr., vol. 10: 2004, pp. 345-352.

[17] J. Sales, and P. J. BRITZ, “Apparent and true availability of amino acids from common feed ingredients from south African abalone (Haliotis midae L.)" Aquacult. Nutr., vol. 9: 2003 , pp. 55-64.

[18] B. Rubbani, M. Afzal, M.S. Mubarik, M. Salim, and S.M., Hussain, "Estimation of apparent digestibility coefficients of soybean meal based diets with different protein levels for Labeo rohita”. Pak. J. Agri. Sci., vol. 48: 2011, pp. 231235

[19] I. Lupatsch, G. Wm. Kissel, "Predicting aquaculture waste from gilthead seabream(Sparus aurata) culture using a nutritional approach". Aquat. Living Resour. Vol. 11: 1998, pp. 265-268.

[20] A. Sintayehu, E. Mathies, K.H. Meyer-Burgdorff, H. Rosenow, and K.D. Guenther, "Apparent digestibilities and growth experiments with tilapia (Oreochromis niloticus) fed soybean meal, Cottonseed meal and sunflower seed meal". J. Applied Ichth., vol. 12: 1996, pp. 125-130.

[21] M. Jindal, S.K., Garg, N.K. Yadava, and R.K., Gupta, "Effect of replacement of fishmeal with processed soybean on growth performance and nutrient retention in Channa punctatus (Bloch.) fingerlings". Livestock Res. Rural Develop, vol. 19: 2007, p. 165. 